\title{
Manifest Criminality, Criminal Intent, and the "Metamorphosis of Larceny"
}

\author{
Lloyd L. Weinreb $\dagger$
}

Professor George Fletcher has described two "general patterns of criminality," which, he says, have explanatory value over a large range of the criminal law. ${ }^{1}$ The "pattern of manifest criminality" requires that conduct punishable as a crime be criminal on its face; its criminality must be "objectively discernible at the time that it occurs. The assumption is that a neutral third-party observer could recognize the activity as criminal even if he had no special knowledge about the offender's intention." 2 In contrast, the "pattern of subjective criminality" takes as its starting point the assumption that "the core of criminal conduct is the intention to violate a legally protected interest." "The only reason we require that offenders act on their intention is to make sure that the intention is firm and not merely fantasy." 4

The "tension" between these two patterns, Professor Fletcher says, "pervades a wide field of the criminal law." He finds some evidence of them in various doctrines of the law. ${ }^{6}$ His principal evidence, however, is the law of larceny, which, he says, underwent a "metamorphosis" at the end of the eighteenth century from the pattern of manifest criminality to the pattern of subjective criminality. ${ }^{7} \mathrm{He}$ argues further that we should resist what he perceives to be the current dominance of the pattern of subjective criminality. ${ }^{8}$ Not only may its emphasis on the actor's intention lead us to

$\dagger$ Professor, Harvard Law School.

1. G. Fletcher, Rethinking Criminal Law 115 (1978) [hereinafter cited without crossreference as Rethinking]. The two patterns are discussed generally in RETHinking at 115-234.

2. Id. at 116 .

3. Id. at 118 .

4. Id. at 119 .

5. Id. at 115 .

6. See pp. 311-16 infra.

7. See pp. 296-310 infra. The historical account of larceny was first presented in an article, Fletcher, The Metamorphosis of Larceny, 89 HARv. L. REv. 469 (1976). Although some of the details have been changed, the accounts in the book and the article are essentially alike.

8. "[T]he resonance of subjective criminality is surely the dominant theme of contemporary criminal jurisprudence." RETHINKING at 234; see id. at 129, 166-67, 173-74. 


\section{Manifest Criminality}

intrude too much into the private realm..$^{9}$ More generally, it reflects a utilitarian, "social engineering" view of the criminal law, which encourages early intervention against a dangerous person, whether or not he is justly subject to punishment for his actual conduct. ${ }^{10}$

We have reason to be grateful to Professor Fletcher for his largescale effort to "rethink" the criminal law. His work reminds us that our search for the values that ought to inform the law has need of the understandings of the past, even if we conclude that they are not adequate to our present situation. Approval of the enterprise, however, does not in this case carry with it agreement with the results. The claims that are made for the explanatory power of these patterns are large, as are the implications drawn from them about the current direction of the criminal law. It is consequently of some importance to set the record straight. Professor Fletcher has seriously misconstrued the historical evidence on which he relies. There was no "metamorphosis" of larceny such as he claims. A theory of manifest criminality does not occupy, above or below the surface, the place he gives it in the development of the English law of theft. Without that historical support, his evidence of two distinct and opposed patterns of criminality consists only of scattered references to the actor's conduct or to his intent, according to the circumstances. The evidence indicates neither, on the one hand, a theory that the criminality of an act had to be manifest on its face nor, on the other, a theory that the actor's intention was the law's main concern and his conduct significant merely as corroboration of criminal intent. Indeed, without the prop of an inaccurate historical record, the idea of "manifest criminality" as a general pattern appears to a considerable degree incoherent.

I agree with Professor Fletcher's general observations about the importance of protecting our private lives from too intrusive efforts to "punish" "dangerous" persons whose conduct has not resulted in actual harm. There is no convincing evidence that the criminal law's strong insistence on criminal intent has led us in that direction. Similarly, I agree that the justice of punishment must be our overriding concern, and that we ought not adopt a simple view that criminal law is merely one among a variety of legal "instruments of social control." In that respect also, the emphasis in

9. Id. at 121,131 . Elsewhere he has written that proving intent as the subjective pattern requires leads to "an intrusive and open-ended investigation into the life of the accused." Fletcher, sufra note 7 , at 473 .

10. Rethinking at 100-02, 118-19, 170-74. 
Anglo-American criminal law on criminal intent has seemed to most observers to be wise. ${ }^{11}$ In a society that rests on fundamental assumptions of human self-determination and responsibility, the requirement of criminal intent as an element of criminal conduct has been a restraint against punishment for unintended harms that are beyond the responsible control of the actor. Of course, Professor Fletcher's injunction against inquiring too far into criminal intent need not be carried to the opposite extreme of disregarding intent altogether. ${ }^{12}$ There is danger, however, that a preoccupation with "manifest criminality" would have that result, so that conduct that appeared "self-evidently" to be criminal would be found without more to be what it appeared. ${ }^{13}$ If we have reason in some areas of the law to be on guard against punishing too soon, without paying close enough attention to the harm to be avoided, we have as much reason to be on guard against punishing simply because harm was done, without attention to the actor's intent, or lack of intent, to do the harm in question. ${ }^{14}$

\section{Larceny}

Professor Fletcher's discovery of a nineteenth-century metamorphosis of the law of larceny rests principally on his analysis of two well-known cases: The Carrier's Case ${ }^{15}$ decided in 1473, and The King v. Pear, ${ }^{16}$ decided in 1779 . In the first case, he says, "we find the principle of manifest criminality most clearly at work." 17 Criminal liability arose out of the "shared image of the thief," which pre-

11. See, e.g., J. Hall, General Principles of Criminal Law 133-41, 325-59 (2d ed. 1947); G. Williams, Criminal Law 255-61 (2d ed. 1961); Hart, The Aims of the Criminal Law, 23 Law \& Contemp. Prob. 401, 413-25, 429-36 (1958).

12. Professor Fletcher would allow a person to prove "non-intent . . . as a challenge to the authenticity of appearances." RETHINKING at 117.

13. Professor Fletcher's own discussion suggests the danger. He acknowledges that there may be no activity "that can always and reliably be identified as criminal." But, he says, it is mistaken "to focus excessively" on problems of intention, since it is "the simple fact of experience... that we can tell when a crime is occurring. In the vast majority of cases what we perceive to be a . . [ [crime] is in fact just that." Rethinking at 116 . See p. 318 infra.

14. See, for example, cases extending responsibility for felony murder beyond deaths caused by the acts of the felons themselves. E.g., Taylor v. Superior Court of Alameda County, 3 Cal. 3d 578, 477 P.2d 131, 91 Cal. Rptr. 275 (1970); People v. Hickman, 59 Ill. 2d 89, 319 N.E.2d 511 (1974). In such cases, the felons' "manifest criminality" has a good deal to do with the willingness of courts to extend their liability to all harms connected with their conduct, whatever their intent.

15. Y.B. Pasch. 13 Edw. 4, f. 9, pl. 5 (1473), reprinted in 64 Selden Soc'y 30 (1945) [hereinafter cited to the Selden Society reprint and translation].

16. 1 Leach 212, 168 Eng. Rep. 208 (Exch. Ch. 1779) [hereinafter cited only to Eng. Rep.].

17. REThinking at 83 . 
vailed over another doctrine that one who had lawful possession of goods could not be convicted of larceny if he misappropriated them. ${ }^{18}$ He contends that Pear, on the other hand, as it was construed by East and later interpreted, made the intent to steal-animus furandi-critical, thus making it possible to convict a person of larceny for an apparently lawful taking of possession accompanied by such intent. Professor Fletcher credits East with having nearly disposed of the requirement of an unlawful act altogether; according to East, he says, "a routine act such as a lessee's laying hands on a horse becomes criminal if at that moment the lessee is visited with the wrong kind of intention." 19 The report of neither case supports these contentions.

In The Carrier's Case, a foreign merchant entrusted his goods to a carrier for transportation elsewhere. Instead of delivering them as charged, the carrier broke open the bales and took their contents. The Yearbook reports a discussion of the question whether the carrier had committed the felony of larceny. ${ }^{20} \mathrm{Had}$ the carrier taken the goods from the merchant against his will there would have been no question; a "trespassory" taking of that sort was the paradigm of larceny. The carrier, however, had received the goods with the merchant's consent; it being understood that a taking from possession was an element of the crime, the carrier's conduct did not conform to the paradigm.

Of the eight persons whose views are reported, seven concluded that a felony had been committed. Five thought that the carrier's intent was the critical issue. ${ }^{21}$ The Chancellor's view is reported in its entirety as follows: "Felony is according to the intent, and the intent here may just as well be felony as if he had not possession."22 Molyneux concluded:

[t]o the same effect. A thing done lawfully may be said to be felony or trespass according to the intent and the circumstances, to wit, if he who committed the act does not carry out the purpose for which he took the goods. . . . [S]o, by his action later, it may be said to be felony or trespass according to the intent etc. ${ }^{23}$

18. Id. at 84 .

19. Id. at 94 .

20. Goods taken feloniously and recovered were "waif," forfeited to the King. The case involved a contest for the goods between the merchant and the sheriff of London, who claimed the goods as the King's delegate.

21. Professor Fletcher disposes of these views in a footnote. Rethinking at $67 \mathrm{n} .31$.

22. 64 SELDEN Soc'y, supra note 15, at 31 .

23. Id. 
Vavasour, likewise, based his conclusion that the carrier had committed a felony on the proof that he had taken the goods "as a felon and with other intent than to carry them."24 Laken also believed that even if the carrier had possession of the goods pursuant to a contract with the merchant, "if he takes them with other intent than to carry them, so that he does not carry out the purpose, it seems that it shall quite well be said to be felony." ${ }^{25}$ Huse played on what we should understand as the distinction between title and possession. Concluding that "the property remains in him who made the bailment," he agreed with the others that if the carrier claimed the goods "feloniously without cause from the party with intent to defraud him to whom the property belongs, animo furandi," it was felony. ${ }^{26}$

Bryan, Chief Justice of the Court of Common Pleas and apparently the conservative of the group, insisted that there was no felony because the requirement of a taking from possession had not been met: " $[F]$ or where they aver that the party has possession by bailment and lawful delivery, there cannot afterwards be said to be felony or trespass touching this." ${ }^{27}$ Needham disagreed. He referred to several not very similar cases to show that the concept of trespass had enough flexibility to cover the facts. ${ }^{28}$ Finally, Choke agreed with Bryan "that where a man has goods in his possession by reason of bailment, he cannot take them feloniously when he is in possession." 29 Nevertheless, he agreed with the majority that the carrier was a felon. The critical fact, he argued, was that the carrier had opened the bales and taken their contents:

$[\mathrm{H}]$ ere the things which were in the bales were not given to him, but the bales as chose entire were delivered ut supra to carry etc. in which case if he had given away the bales or sold them, it would not be felony, but when he broke open and took out of it what was inside, he did this without warrant. ${ }^{30}$

24. Id.

25. Id. at 33 .

26. Id. at 31 .

27. Id. at 30-31.

28. Id. at 33. The cases to which Needham referred are: (1) a person who has entrusted goods to another secretly removes them, intending to recover damages from the other person for their loss; (2) the owner gives goods to another person who is to deliver them to the owner's house; after having delivered the goods to the house, the person carrying them takes them away again; (3) a person having a drink in a tavern makes off with the cup in which the drink was served; and (4) a servant carries off his master's goods from the master's house. Needham evidently regarded the first case as a variant illustration of the principle exemplified by the latter three.

29. Id . at 31-32.

30. Id. at 32 . 
Choke found this curious distinction in two situations that he thought analogous.

Thus if a man is given a tun of wine to carry, if he sells the tun, it is not felony or trespass, but if he took out twenty pints it is felony, for the twenty pints were not given to him, and peradventure he had no knowledge of it at the time of the bailment. So it is if I give the key of my chamber to anyone, if he takes my goods in this chamber, it is felony for they were not given to him. ${ }^{31}$

All of these views express concern for the familiar elements of larceny, felonious intent and a taking from possession, without reference to the thief's "manifest" behavior. It requires more than a little ingenuity to find evidence of "the principle of manifest criminality ... at work" 32 or even on the job site. Professor Fletcher argues nevertheless that it is there. The aspect of manifest thievery, he says, "is captured in the moment of breaking of the bales; the judges were less likely to sense thievery in the acts of selling or giving away the bales." ${ }^{33}$ Aside from the puzzle of why we should suppose, contrary to the statements of most of those whose views are reported, that judges and lawyers of the time would not equally have "sensed thievery" if the carrier had sold or given away the unbroken bales, ${ }^{34}$ there is simply nothing in the report of the case to support Professor Fletcher's analysis. He finds support in Needham's reference to an owner who, having entrusted goods to another person, comes "secretly like a felon" and retakes them. That, Professor Fletcher says, is "an explicit reference to the principle of manifest criminality." ${ }^{35}$ The passage from which those words are drawn will hardly bear that construction. The example of the owner is but one of several in the same passage, which Needham offers to show the possibility of trespass in situations where the thief had previously held the property lawfully. ${ }^{36}$ Read in its entirety,

31. Id.

32. See p. 296 supra (quoting RETHINKING at 83).

33. Rethinking at 83 .

34. Professor Fletcher recognizes that he solves the puzzle only by "a stipulation about the knowledge attributable to ideal observers," and admits that by application of appropriate stipulations, any conduct will be "manifestly criminal." RETHINkING at 83 . He does not explain why one stipulation rather than another is appropriate, however, except apparently by reference to the "conventional acceptability of the behavior under the circumstances," id. That is of no help in The Carrier's Case. The same stipulation that would make breaking bulk manifestly criminal would make a sale or gift of the goods equally manifestly criminal or more so. See pp. 310-11 infra.

35. Rethinking at 84 .

36. See note 28 supra. The reference to secrecy in the example on which Professor 
particularly in the context of the general discussion, Needham's view no more than any of the others indicates that a notion of "manifest thievery" was significant explicitly or implicitly in the reasoning of the court.

The inapt reference to Needham aside, Professor Fletcher does not claim that the theory of "manifest criminality" is manifest in the report of The Carrier's Case itself. Rather, that theory is the key to an "enigma" of the common law; ${ }^{37}$ it explains why Choke's doctrine of "breaking bulk" became the rule of the case. "The significance of the Carrier's Case," he says, "is that it was received into the tradition as holding that manifest criminality should prevail over the principle of possessorial immunity." 38 Once again, however, there is no historical evidence to support this assertion.

All of the commentaries on The Carrier's Case down to the end of the eighteenth century (when, according to Professor Fletcher's theory, the element of intent in larceny became prominent) discussed it in the context of felonious intent and trespassory taking. Professor Fletcher states, "Blackstone was apparently the first commentator to explicate the rule of 'breaking bulk' as an instance of manifest criminality." 39 Blackstone, however, explicates the rule simply as an instance where there is the requisite proof of felonious intent. His actual statement is that in a case of breaking bulk and others that he mentions, "the animus furandi is manifest." ${ }^{40} \mathrm{His}$ analysis of larceny unmistakably requires both a taking and, as a separate matter, proof of animus furandi, the felonious intent. He treats the requirements of a taking and felonious intent in separate sections, numbered separately and separated by a discussion of the further requirement of a carrying away. ${ }^{41}$ Not only is there no affirmative indication of a requirement of manifest criminality. The conclusion of his discussion of felonious intent speaks conclusively to the contrary:

The ordinary discovery of a felonious intent is where the party doth it clandestinely; or being charged with the fact, denies it. But this is by no means the only criterion of criminality; for in cases that may amount to larceny the variety of circumstances

Fletcher relies simply fulfills the requirement that the owner's retaking of his goods be trespassory, that is, against the will of the then-lawful possessor.

37. Rethinking at 60 ; see id. at 66,83 .

38. Id. at 84 .

39. Id. at 84 n.33.

40. 4 W. Blackstone, Commentaries $* 230$.

41. Id. at $* 230-32$. 
is so great, and the complications thereof so mingled, that it is impossible to recount all those, which may evidence a felonious intent, or animus furandi: wherefore they must be left to the due and attentive consideration of the court and jury. ${ }^{42}$

Other commentators before and after Blackstone give the same account. Coke, for example, on whose authority Blackstone relied for the rule of breaking bulk, discusses the elements of felonious intent and "an actual taking" separately, and nowhere suggests integrating the two as "manifest criminality." 43 Breaking bulk is mentioned as one of several special examples in Coke's discussion of taking, without any indication that the examples are to be explained by that theory. ${ }^{44}$ Hale and Hawkins are to the same effect. ${ }^{45}$ Two commentators express puzzlement about the rule making breaking bulk especially significant, in terms that contradict a theory of manifest criminality. Dalton, referring to the same argument about "property" that Huse had made, ${ }^{46}$ wonders why a carrier who took the goods would not be guilty even if he did not break bulk. ${ }^{47}$ Kelyng is still more explicit:

But I marvel at the Case put, 13 E.4.9.b. That if a Carrier have a Tun of Wine delivered to him to carry to such a Place, and he never carry it but sell it, all this is no Felony; but if he draw part of it out above the Value of Twelve pence, this is Felony; I do not see why the disposing of the whole should not be Felony also. ${ }^{48}$

Writing in 1803 , East observed that, with one exception, "all other writers, as far as I can find, have put this case upon the same footing as Lord Hale; namely, that the privity of contract is determined by the act of breaking the package which makes him a trespasser." 49

42. Id. at *232. Blackstone was borrowing, directly or by way of some intermediate borrower, almost identical language in Hale's History of the Pleas of the Crown, which had been available in manuscript and was published in full in 1736. $1 \mathrm{M}$. HaLe, The History of the Pleas of the Crown 509 (London 1736).

43. E. Coke, Third InstrTute 107-08 (London 1644).

44. Id.

45. M. Hale, Pleas of the Crown 49-51 (London 1678); 1 M. Hale, supra note 42, at 504-09; 1 W. Hawkins, a Treatise of the Pleas of the Crown 90 (London 1716). See also M. Dalton, The Countrey Justice 230-31 (London 1618); W. Stanford, Les Plees DEL Coron 25 (London 1557).

46. See p. 298 supra.

47. M. DALTON, supra note 45 , at 231 .

48. J. Kelyng, a Report of Divers Cases in Pleas of the Crown 83 (London 1708).

49. 2 E. East, A Treatise of the Pleas of the Crown 697 (London 1803). The exception was Kelyng, who thought that the significance of breaking bulk was that it supplied 
Professor Fletcher states that under the theory of manifest criminality as it developed in this period, "[t]he primary inquiry was the act of larceny"; "the law was structured so as to render intent a subsidiary issue," which arose "only in extraordinary cases." ${ }^{50}$ One can only ask what is the basis for the statement. It is beyond dispute that none of the commentators thought that the law was so structured. Coke, for example, begins his discussion of the elements of larceny with intent: "First it must be felonious, id est, cum animo furandi, as hath been said. Actus non facit reum, nisi mens sit rea." ${ }^{11}$ Far from perceiving the issue of intent as at all extraordinary, Hale and Blackstone conclude their discussion of intent with an admonition that the variety and complexity of circumstances that may evidence felonious intent are so great that it is impossible to recount them and they must be left to the court and jury. ${ }^{52}$ The commentaries contain examples of cases in which the finding of larceny depends on the actor's fraudulent intent, an element that is not visible at all in "the act of larceny" and must be proved independently. Professor Fletcher mentions the examples of larceny in fraudem legis that involved a fraudulent use of legal process. ${ }^{53}$ There are others as well, all of them inconsistent with the generalization that " $[t]$ he issue of intent in larceny was not thought of separately from the manifestation of that intent in the external world." 54

proof of the necessary felonious intent. See J. Kelyng, supra note 48, at 81-83. Blackstone may also have adopted that analysis. See $4 \mathrm{~W}$. BLACKstone, supra note 40 , at $* 230$. Both Kelyng and Blackstone place their discussion of breaking bulk in The Carrier's Case within a general discussion of the requirement of a taking. Although they looked on breaking bulk as evidence of felonious intent, that fact was significant not only in itself but also (and at least in Blackstone's case primarily) because thereby the delivery did not preclude a finding of the necessary trespass.

50. Rethinking at 86.

51. E. CoKE, supra note 43 , at 107 .

52. See p. 301 \& note 42 supra.

53. RETHINKING at 85 n.35.

54. Id. at 85. The particular case of larceny in fraudem legis that Professor Fletcher discusses involved looting following enforcement of a fraudulently obtained writ of ejectment, facts that perhaps can be accommodated to manifest criminality. Other such cases are not so easily accommodated, for example, the fraudulent use of legal process to obtain delivery of someone else's horse, discussed in E. CoKE, supra note 43, at 108; I M. HALE, sufra note 42 , at 507; 1 W. Hawkins, supra note 45 , at 90 . Examples of larceny not involving abuse of legal process where intent is critical are given in I M. HALE, supra note 42, at 507 ("If the sheep of $A$. stray from the flock of $A$. into the flock of $B$. and $B$. drives them along with his flock, or by pure mistake shears him, this is not a felony, but if he know it to be another's, and marks it with his mark, this is an evidence of a felony."); id. at 509, and in $1 \mathrm{~W}$. Hawkins, supra note 45 , at 91 (lodger who rents lodgings with intention to steal the furniture and does so is guilty of larceny "inasmuch as his whole Design was to defraud the Law, and the Consent of the Owner was grounded on the Supposition of his coming as a Lodger, and could never have been gained if the Truth had appeared, which the Party 
There is, in short, no evidence either in the report of The Carrier's Case or its subsequent treatment to support Professor Fletcher's novel theory, and very strong evidence in both to contradict it. Even if one were to ignore the evidence, the theory on its own terms is dubious as a solution for the enigma that he finds in the case. Suppose two carriers are hired to deliver the merchant's goods to Southampton: one breaks the bales and goes off with the contents; the other sells the bales intact to a stranger, pockets the proceeds, and departs. Which of the two is, at that moment, the more "manifest" thief? Can we suppose that, whatever he might think of the first carrier, the merchant would not immediately cry "Thief" if he observed the transaction of the second? It is difficult to believe that one displays his felonious intent so much more clearly (if at all) than the other, as Professor Fletcher's theory requires. ${ }^{55}$ In fact, although Choke's analysis is not unassailable, his reliance on breaking bulk is understood much more easily on the ground that Choke himself stated, as an analogy to the earlier cases in which a trespassory taking was found despite a prior delivery, than on a covert intuition of manifest thievery. ${ }^{56}$

If The Carrier's Case is not given the special meaning with which

shall get no Advantage by falsifying"). Kelyng describes Hawkins' example of the lodger as a case of larceny in fraudem legis. J. KELYNG, supra note 48 , at 82 . If it is so regarded, that category of larceny, which Professor Fletcher regards as exceptional, is not limited to abuse of legal process and obviously anticipates larceny by trick as it was described in The King $v$. P'ar. S'e pp. 306-08 infra.

55. See note 34 supra.

56. Professor Fletcher criticizes the analysis of authorities like Stephen and Hall, who, he says, make " $a$ priori arguments about the necessary influence of social and political forces in shaping the law." Rethinking at 68 . A simpler way to satisfy the forces that they suggest favored protection of the alien merchant, he says, would have been to declare that the taking was not felonious, in which case the merchant would have recovered his goods. That argument, like his argument that the protection afforded to merchants by application of the criminal law was offset by the risk that goods would be lost as waif, see p. 297 \& note 20 supra, is a blinkered response to Hall's much more general, convincing account of the policies that supported giving the protection of the law to merchants who entrusted their goods to others for commercial reasons. See J. HALl, ThEFr, LAw AND Society 14-33 (2d ed. 1952). (In fact, having declared that there was felony, the judges nevertheless managed to return the goods to the merchant, on the ground that he was an alien to whom the King had granted a covenant of safe and secure conduct, so that the King could not claim the stolen goods as waif. 64 SELDEN Soc'y, supra note 15, at 34.)

Professor Fletcher urges also that even if Hall's account is accurate, it fails to explain why the line was drawn just where it was, rather than broadly enough to include all cases of a carrier who made off with a merchant's goods. Rethinking at 69-70. The conceptual importance of the element of trespass coupled with the analogies on which Choke relied, st' p. 298 supra, furnish an explanation. Cf. T. Plucknett, A Concise History of the Common Law 449 (5th ed. 1956); $3 \mathrm{~J}$. Stephen, History of the Criminal Law of ENGLAND 139 (1883). As noted above, pp. 297-98 supra, a majority of those whose views are expressed were willing to go the further distance. Later commentators relied on Choke's analysis, but none of them supports Professor Fletcher's theory. 
Professor Fletcher invests it, the other evidence that he offers for a pattern of manifest criminality in the crime of larceny up to the end of the eighteenth century lacks persuasiveness. There were a variety of situations in which the law held that it was larceny to misappropriate goods that had been lawfully acquired for a limited purpose.$^{57}$ Professor Fletcher suggests that once again the principle of manifest criminality is at work; here, he says, it expands criminal liability by rejecting the rule of possessorial immunity "in those cases in which the taking typically conformed to the shared image of thieving." ${ }^{58}$ His analysis is considerably tortured, however, as he recognizes, by the difficulty of explaining how criminality is more "manifest" in the cases that were held to be felony than in those that were not. ${ }^{59}$ The cases are far more sensibly understood as applications of the flexible notion of trespass already evident in The Carrier's Case. With sufficient determination, one can force that element of larceny into the framework of manifest criminality; one way or another, any aspect of a situation that is found to satisfy the requirement of trespass can be described as the necessary manifestation. But the idea of manifest criminality, referring to a distinct group of acts manifestly criminal in themselves, then loses all meaning. It is, in any event, superfluous and not what is discussed in the cases.

Professor Fletcher's remaining evidence for his theory in the crime of larceny is surprisingly a line of modern cases that he describes as "staged larceny": cases in which a would-be thief is suspected in advance and allowed to carry out the would-be theft be-

57. Chisser's Case, 83 Eng. Rep. 142 (K.B. 1678), furnishes an example. Chisser asked to see two cravats, which the shopkeeper put into his hands. He asked their price and, after offering her a smaller sum, immediately ran out of the shop with the cravats. According to the report, Chisser was guilty because

[a]lthough these goods were delivered to Chisser by the owner, yet they were not out of her possession by such delivery, till the property should be altered by the perfection of the contract, which was but inchoated and never perfected between the parties; and when Chisser run away with the goods, it was as if he had taken them up, lying in the shop, and run away with them. Id. at $142-43$.

Professor Fletcher suggests that Raymond, the reporter of the case, provided two distinct analyses of the result: the one above, which makes Chisser guilty when he runs away, and another, which would make Chisser guilty when the cravats were delivered to him. The former is said to appear in the third paragraph of the report and the latter in the second paragraph. See Rethinking at $99 \&$ nn.38 \& 40; Fletcher, supra note 7, at 487 n.78, 513 n.176. The entire report consists of three paragraphs. Such a reading of it is not serious. Professor Fletcher also mistakenly attributes the nonexistent alternative analysis of Chisser to East. Rethinking at 99; see 2 E. EAST, supra note 49 , at 683,687 . See generally pp. 307-08 infra.

58. Rethinking at 83 .

59. Id. 
fore he is caught. In such cases, he asserts, it is the absence of "the features of manifest criminality" that accounts for the acquittal of "obviously dishonest and dangerous people." ${ }^{60} \mathrm{He}$ makes the opinion in Topolewski $v$. State ${ }^{61}$ the focus of his discussion. ${ }^{62}$ There the defendant sought to enlist the aid of Dolan, a former employee of a meat-packing company, to steal some barrels of meat. Dolan reported the plan to a supervisor at the company, who directed him to feign cooperation. The defendant and Dolan discussed various plans and agreed on one, which Dolan reported to the supervisor. The supervisor arranged for barrels of meat to be placed on the loading platform pursuant to the plan, and instructed the platform boss, who knew nothing of the plot or counter-plot, to let the person who came for the barrels take them away. The defendant loaded the barrels onto his truck and drove off.

As Professor Fletcher recognizes, the opinion is addressed plainly to the issue of trespass: whether the acts of the company's personnel went too far in cooperation with the defendant and constituted a delivery of the barrels, so as to "take from the transaction the element of trespass or nonconsent essential to the crime." 63 However, he regards all of the discussion, repeatedly cast in terms of delivery or trespass, as in reality only "effective rhetoric" to reveal the underlying dispositive pattern of manifest criminality. ${ }^{64}$ Unless once again he is simply rendering "manifest criminality" as a synonym for trespass, that is a gratuitous analysis. The court observes that the requirement of a trespass

does not militate against a person's being free to set a trap to catch one whom he suspects of an intention to commit the crime of larceny, but the setting of such trap must not go further than to afford the would-be thief the amplest opportunity to carry out his purpose, formed without such inducement on the part of the owner of the property, as to put him in the position of having consented to the taking. ${ }^{65}$

One who took advantage of such an opportunity plainly need not have been acting any differently on the surface of things than a

60. Id. at 70, 86. The cases that Professor Fletcher discusses arose after the claimed "metamorphosis of larceny" that is supposed to have done away with manifest criminality; but, he says, "it survives in corners of the law, such as cases on staged larceny." Id. at 234.

61. 130 Wis. 244, 109 N.W. 1037 (I906).

62. Rethinking at $72-76,86-88$.

63. 130 Wis. at 250,109 N.W. at 1039 .

64. Rethinking at 86.

65. 130 Wis. at $254-55,109$ N.W. at 1041 . 
person acting lawfully. Yet, according to the court, there would be trespass and hence larceny. What persuaded the court that the company's connivance had gone too far was the combined effect of Dolan's discussion with the defendant and agreement to assist him, the placing of the barrels on the loading platform pursuant to the plan, and the platform boss's presence and indications of consent while the barrels were loaded. ${ }^{66}$ Even with all that the court thought the facts were near the borderline. ${ }^{67}$ There is no need or reason to go beyond the court's own analysis in terms of trespass and look for a suppressed intuition of what it is to behave like a thief. 68

The sum of the preceding discussion is that the law of larceny as it developed up to the decision of Pear in 1779 displayed consistent attention to the requirements of felonious intent and a trespassory taking. The latter element referred to the paradigm of a literal taking from possession against the will of the possessor, but was extended in a variety of situations to other appropriations by one doctrinal device or another. The cases and the commentary reveal no concern for "manifest criminality."

The King v. Pear marked no departure from that development. Pear rented a horse from Finch's livery stable. He told Finch that he intended to ride to Sutton and would return that night; also, he lied to Finch about his address. Instead of going to Sutton, he sold the horse. At his trial for larceny, the jury found specially that he intended to sell the horse when he rented it. Upon that finding, he was convicted. The case was referred to the whole court, a majority of which upheld the conviction. They concluded that, Pear's original intention having been fraudulent, "the parting with the property had not changed the nature of the possession, but that it remained unaltered in the prosecutor at the time of the conversion." ${ }^{99}$ That analysis is, of course, no more than another application of the familiar device of leaving possession "constructively" in the owner; ${ }^{70}$ the sale of the horse contrary to the terms of the rental agreement (or perhaps some prior violation of the terms) was then a conversion, and the requirement of trespass was

66. Id. at $250,256-57,109$ N.W. at 1039,1041 .

67. Id. at 251,109 N.W. at 1039 .

68. Indeed, having asserted that his "account of acquittal in cases of staged larceny demonstrates the explanatory value" of the pattern of manifest criminality, Professor Fletcher immediately goes on to acknowledge that the explanation is ad hoc and not adequate to deal with closely similar cases. RETHINKING at 87-88.

69. 168 Eng. Rep. 208, 209 (Exch. Ch. 1779).

70. See note 28 supra. 
satisfied. The device was a fiction, to be sure. We may agree that the judges were inventive; but the necessity that was the mother of their invention was the traditional conception of larceny that made a trespassory taking essential. No "metamorphosis" was anticipated and none was wrought.

Professor Fletcher declares, however, that when East wrote his version of the case, which was published in 1803, he radically altered the judges' reasoning. East, he says, interpreted Pear to eliminate the requirement of a conversion altogether, so that "Pear could have been arrested as soon as he mounted the horse."71 East's interpretation, he adds, which made Pear's crime depend on his intent when he received the horse, gave expression to a new attitude toward criminality that elevated the importance of intent and made manifest criminality secondary. ${ }^{72}$

It is difficult indeed to read East's report of Pear as Professor Fletcher does. The report is thorough and detailed; nowhere does East suggest a disagreement with the earlier report of Leach. Discussing the facts of the case, he says that "the obtaining the possession of the mare, and afterwards disposing of her in the manner stated" was a trespass, which, accompanied by "felonious intent at the time of obtaining the possession," constituted larceny at common law. ${ }^{73}$ In a series of examples to illustrate the rule on which the judges relied, he includes the element of a conversion. ${ }^{74}$ Since Pear had sold the horse, there was no dispute that there had been a conversion. Far from eliminating that requirement, East plainly took it for granted. Professor Fletcher presumably relies on several statements out of context, to the effect that a taking with felonious intent constitutes larceny. Such statements are part of East's discussion of the circumstances in which a delivery precludes finding the trespass essential to larceny. He emphasized the distinction between a taking with felonious intent at the time of taking (as in Pear), in which case there may be larceny, and a taking without such intent, in which case there would be no larceny despite a subsequent conversion. Professor Fletcher's argument might be compared to the suggestion that the statement, "An unlawful killing with malice aforethought is murder, without malice aforethought manslaughter,"

71. Rethinking at 94. "A subsequent conversion of the horse would not be required and Pear presumably could have been arrested as soon as he left the stable." Fletcher, supra note 7, at 507.

72. Rethinking at 94-95.

73. 2 E. EAST, supra note 49 , at 688 (emphasis added).

74. Id. at 687 . 
puts in doubt the requirement that the victim of a homicide be a human being. Were this reading of East plausible, it would be astonishing that none of the nineteenth-century commentators picked it up. ${ }^{75}$ In any event, even without East's supposed alteration, it is impossible to find "manifest criminality" in Pear's conduct; obviously, if his criminality had been manifest to Finch, who was on the scene, Finch would not have rented him the horse. ${ }^{76}$ The judges in Pear, like their predecessors, were concerned to decide whether the facts of the case fit, or could reasonably be made to fit, the requirements of trespass and felonious intent.

Judges in the nineteenth century sometimes proved willing to find trespass far from the paradigm, for example in circumstances where, because of accident or mistake, the defendant acquired possession without initiative on his part or direct interference with the owner's interest. ${ }^{77}$ Rather than reflecting any "metamorphosis," such cases were simply extensions to new situations of the traditional pattern of thought. Professor Fletcher correctly discerns in such cases, as well as in the extension of other crimes against prop-

75. The suggestion in Fletcher, supra note 7, at $513 \mathrm{n} .177$, that the "new view of larceny" originating with East (which eliminated the requirement of a conversion) is reflected in Russell's nineteenth-century treatise, is based on a misunderstanding of the text on which Professor Fletcher relies. The authors of the treatise discuss the case of Regina v. Brooks, 173 Eng. Rep. 501 (1837), in which the defendant hired a horse and gig and then offered to sell them to one Orbell; Orbell, being suspicious because of the low price, pretended to agree to the purchase and, pretending to go to get the amount, summoned a constable. Far from eliminating the requirement of a conversion, the authors argue that in the peculiar circumstances, "as against ... [the defendant] it might well have been held that the conversion was complete." 2 W. Russell, Treatise on CRimes and Misdemeanors 54-55 n.r (5th American from 3d London ed., C. Greaves ed. 1845). The treatise discusses Pear several pages above the quoted passage and cites both Leach's and East's reports without distinguishing them. The discussion does indeed make Pear's intention at the time he obtained possession critical, but on the assumption, common also to Leach and East, that there was a subsequent conversion. See id. at $\mathbf{5 0}$.

76. Professor Fletcher observes that the unaltered version of Pear "was at least partially compatible with the traditional conception of larceny as manifest thievery. The moment of thieving was displaced by the subsequent conversion and selling of the horse, which manifested the purpose of misappropriation." Rethinking at 93-94. That simply ignores the unmistakable focus on Pear's intent when he rented the horse. Such analysis illustrates how the term "manifest criminality" can be used to refer to whatever act constitutes the necessary trespass, without adding to our understanding.

77. E.g., The Queen v. Middleton, L.R. 2 Cr. Cas. Res. 38 (1873); The Queen v. Ashwell, 16 Q.B.D. 190 (1885). Professor Fletcher discusses these cases in RETHINKING at 107-10. He asserts that Middleton is a "critical" case, which made "a radical extension of the law of larceny." Id. at 107, 108. Once again, he incorrectly interprets the opinions as disregarding the requirement of a conversion, which, as the majority analyzed the facts, was present beyond dispute. Bramwell, in dissent, thought that the case involved "great and important principles," L.R. 2 Cr. Cas. Res. at 54 . But he would have been considerably surprised to learn that what was so importantly at stake was "the requirement of an objectively criminal act," RETHINKING at 109 n.28. 
erty, the law's increasing focus on dishonest acquisition as the core of theft. The importance of protecting the interest in property made it less important to distinguish one wrongful mode of acquisition from another, especially if preservation of the distinctions made it likely that some such acquisitions would slip through the cracks and not be criminal at all. ${ }^{78}$ It may be that the pressure for comprehensiveness was more intense in the nineteenth century than it had been earlier. More likely, perhaps, that pressure is simply more apparent to us than comparable pressures in earlier centuries to declare criminal acts that at the time seemed to be clearly wrongful but nevertheless to lie at or just beyond the furthest reach of the criminal law. Professor Fletcher is scornful of the assumption "that the law always responds to the "felt necessities of the time." "79 In fact, the law of theft is an excellent example of the interplay between legal doctrine and changing social perceptions. Changes in the law of larceny, accompanied by parallel changes in the law of embezzlement and false pretenses, reflect with unusual clarity a continuous development of that kind.

The outcome in England and this country alike was reformulation of the law to replace the distinct crimes defined according to method, with all the consequent difficulties of classification when the facts fell along the borderlines, by a comprehensive crime of theft. ${ }^{80}$ We should not suppose, however, that the process has necessarily come to an end. From a comparable vantage, we might find conduct that we now regard as beyond the scope of criminal law as plainly criminal as the carrier's conduct. We should not assume too readily that commercial practices, including perhaps some forms of sales promotion, or methods of business competition, or violations of contractual rights, will not, under pressure of changing shared values, be perceived as theft. Or, though this

78. For a famous American example of such a lucky thief, see Commonwealth v. King, 202 Mass. $379,388-89,88$ N.E. 454,458 (1909), reporting the case of O'Malley, who was acquitted of larceny because the judge thought his crime was embezzlement and whose subsequent conviction of embezzlement was reversed because the appellate court concluded that his crime was larceny after all.

The effort to fill the cracks is particularly evident in legislative responses, such as the first English general embezzlement statutes, 39 Geo. 3, c. 85 (1799), in response to The King v. Bazeley, 168 Eng. Rep. 517 (Exch. Ch. 1799), and 52 Geo. 3, c. 63 (1812), making the coverage of embezzlement still more complete, in response to The King v. Walsh, 168 Eng. Rep. 624 (Exch. Ch. 1812), which had held that the prior statute did not cover a stockbroker.

79. Rethinking at 68 (quoting O.W. Holmes, The Common Law 1 (1881)).

80. In England, consolidation was effected by the Larceny Act of 1916, 6 \& 7 Geo. 5, c. 50, revised and simplified by the Theft Act 1968, c. 60. For a model American statute, see the Model Penal Code $\$ \S 223.0-9$ (1962). 
seems less likely, we might no longer regard certain conduct that today constitutes theft as appropriate for the criminal law.

\section{Manifest Criminality}

The theory of manifest criminality proceeds from the assumption that the criminal aspect of prohibited behavior can ordinarily be perceived simply by observing the criminal act; the crime as criminal is "a recognizable event in the physical world." actor's intent to steal did not manifest itself in an externally identifiable act of stealing, no larceny could be committed." 82 The thesis should not be confused with a strong, even a very strong, requirement that guilt be proved with certainty. The thesis is not about proving guilt at all. It is about the nature of the acts that are deemed criminal. ${ }^{83}$ Professor Fletcher's argument is that where it is applicable, that approach to the definition of crimes is distinct from and preferable to the approach that defines crimes by the conjunction of prohibited conduct and criminal intent and allows the two to be established independently. ${ }^{84}$ The assumption that criminality can generally be perceived as an observable characteristic of the events that properly constitute crime is wrong. Furthermore, effort to press it into service in place of explicit reliance on proof of criminal intent would very likely harm the values of liberty and privacy that Professor Fletcher wants to protect.

Whatever plausibility the notion of manifest criminality has in the particular context of theft derives from the fact that the paradigm includes a physical trespass, an actual taking of property from the possession of another person. Even in that setting, it is not difficult to imagine conduct that "externally" appears to be theft but in fact is not. An observer who comes across two persons struggling for possession of some object, say a bicycle, will not be able to tell just from what he sees and hears which of the two is a thief, or whether either is a thief, or even-if we exercise our imaginations-whether both may not be thieves. We need to know at least who owns the bicycle. If that sort of information is to be included in Professor Fletcher's definition of a "recognizable" or "externally identifiable" event in the physical world we are already a

81. Fletcher, supra note 7, at 476. See p. 294 supra.

82. Fletcher, supra note 7 , at 473 .

83. Rethinking at $119,232$.

84. Professor Fletcher has made it clear that he does not believe that the theory of manifest criminality has any application at all to large areas of criminal conduct. See pp. 315-16 infra. His preference for the pattern of manifest criminality is indicated in RETHINKING at $89,121,131$. It is stated more strongly in Fletcher, supra note 7, at 528-29. 
long way from manifest criminality. ${ }^{85}$ Even that, of course, will not be enough. One bicycle is often enough mistaken reasonably and genuinely for another. Or Smith and Jones may be struggling for possession of Brown's bicycle, Smith because Brown has loaned it to him and Jones because he believes that someone is about to make off with his friend Brown's bicycle. Or any number of things. Professor Fletcher's "shared image of the way thieves act" 86 is in fact a caricature of thievery: the masked bandit who creeps up from behind, clubs his prey and makes off with the loot. In the multiform real world, we cannot rely so comfortably on appearances.

If we look beyond crimes that involve some physical act directed toward a person or his property, the idea that criminality is visible on the surface of an event loses its plausibility altogether. Quite aside from Pear's secret intent, when he lied to Finch was that manifest thievery or not? (That it was a lie was, of course, not part of an "externally identifiable act.") Suppose he hadn't lied when he rented the horse and instead of selling it had ridden it to a place other than Sutton. Is that manifest thievery or only a violation of the rental agreement? Of course, we might wait to see what Pear does with the horse later. But then the notion of a manifest crime committed at an identifiable moment has to be abandoned. We have in fact come close to the unexceptionable principle, not only in criminal law but in ordinary affairs, that a person's intent can often be proved by a course of conduct over time. If we see someone in a restaurant remove another person's coat from a rack and walk out with it, have we seen manifest thievery or not? If not, is a person who deliberately selects the most attractive coat on the rack not to be prosecuted? But if so, is everyone of us who had made such a mistake presumptively a thief? If one person induces another to buy something by a material misrepresentation of fact-once again, not something observable as part of the act-is that manifest thievery? Do we not need to determine whether the misrepresentation was an honest mistake or a deliberate falsehood-that is, the intent behind the act?

Professor Fletcher makes a sustained effort to uncover the pattern of manifest criminality in criminal attempts. He suggests that there are two approaches to the definition of an attempt: a "minimalist" approach allied to an " 'objectivist' theory of attempts" and

85. Of course, if we make the appropriate "stipulations," there is no problem. See note 34 supra.

86. Rethinking at 116. 
a "maximalist" approach that is allied to a "subjectivist" theory. ${ }^{87}$ The former is closely related to the pattern of manifest criminality; the latter, preoccupied with the issue of intent, to the pattern of subjective criminality. This analysis is applied to two recurrent problems in the law of attempts: (1) the distinction between "mere preparation" for a crime, which is not itself criminal, and an attempt, which is; and (2) whether an "impossible" attempt that is bound not to succeed is nevertheless criminal in itself.

As Professor Fletcher acknowledges, there has been little enthusiasm in this country or in England for a criterion of manifest criminality as the distinction between acts of preparation and a criminal attempt. ${ }^{88}$ But, he suggests, its virtues have not been "fully aired." 89 One of its virtues, he argues, is its resistance to the "social engineering" or "administrative" approach to criminal law that would favor the confinement of dangerous persons. The subjectivist approach, he says, shifts our attention "from the dangerousness of acts to the dangerousness of persons; even an act that is not dangerous in itself can reveal the actor to be dangerous." ${ }^{90}$ There has been a continuing debate about how far in advance of a completed crime the line marking an attempt has been crossed. What Professor Fletcher describes as the subjectivist approach is nowhere evident; it has neither been espoused nor adopted. It is not a coincidence that he mentions no case in which the "subjectivist" distinction between preparation and attempt is made. ${ }^{91}$ Recent cases

87. Id. at 138 .

88. The name most closely associated with a requirement that the act by itself manifest the criminal intent is Judge Salmond of the Supreme Court of New Zealand. He stated the requirement in The King v. Barker, [1924] N.Z.L.R. 865, 872, 874-75 (Ct. App.) Relying principally on the authority of Salmond, New Zealand for a time followed that rule. See Campbell v. Ward, [1955] N.Z.L.R. 471, 474, 476. That is no longer the law. Crimes Act, $1961, \S 72(3)$ (No. 43).

Sometimes it is said that the conduct constituting an attempt must be "unequivocal." It is doubtful whether such language adopts Salmond's view that the act constituting the attempt has to establish the necessary intent without reference to other circumstances or evidence of intent. The testing case would be one in which there were an act otherwise satisfying that element of an attempt and unequivocal proof of criminal intent that was not contained entirely in the act itself.

89. RETHINKING at 143 .

90. Id. at 174 ; see id. at $143-44,173-74$.

91. Professor Fletcher perceives the Model Penal Code formulation as reflecting the "subjectivist" approach. Id. at 167-68. The Code requires (in addition to the necessary intent) "an act or omission constituting a substantial step in a course of conduct planned to culminate in his commission of the crime." Model Penal Code $\$$ 5.01(1)(c) (1962). It provides further: "Conduct shall not be held to constitute a substantial step under Subsection (1)(c) of this Section unless it is strongly corroborative of the actor's criminal purpose." Id. $\$ 5.01(2)$. The latter section then lists certain kinds of conduct, like lying in wait, which "if strongly corroborative of the actor's criminal purpose" are not insufficient as a matter of 
that have discussed the distinction between preparation and attempt have shown no tendency to convict a general category of dangerous persons whose concrete conduct constituting the attempt did not indicate a strong likelihood of commission of the underlying offense. ${ }^{92}$

The second virtue that is claimed for the criterion of manifest criminality to distinguish preparation from attempt is that it ties criminal attempts closely to the kind of conduct that arouses public apprehension and is "unnerving to the community."93 Professor Fletcher recognizes that dependence on "the sentiments of the local community" is not an unmixed blessing for the criminal defendant; we cannot count on a community's apprehensions always to be rational and just. ${ }^{94} \mathrm{He}$ suggests, however, that the risk of being tyrannized by sentiments of unreason can be avoided if we rely on "the community's sense of what is criminal and unnerving" only to articulate rules "based on criteria of manifest criminality," and not to decide particular cases. ${ }^{95}$ Experience may not assure the rest of us that the unexamined apprehensions of the community are a reliable source even for the rules or that once having appealed to them for that purpose we shall so easily put them aside when the rules are applied. In any case, it is evident that our hope and endeavor must be precisely that the rules and their application not respond without the mediation of other principles to what the community regards as a manifestation of criminality.

The problem of impossibility in criminal attempts has confused and bemused courts, commentators, teachers, and students alike.

law. It is true that drafters of the Code intended to draw "the line between attempt and noncriminal preparation further away from the final act." Id. \$§ 5.01-.05, Comment, at 25 (Tent. Draft No. 10, 1960). Nevertheless, the Code hardly fits Professor Fletcher's description of subjectivist theory:

The subjective approach is defined by the rejection of the claim that the act of attempting is a distinct dimension of liability. For subjectivists, it is important that the actor take steps to execute his criminal intent, yet no specifically defined act is required for liability. This means that no conviction should ever founder on the ground that there was something wrong with the "act" element of attempting.

RETHiNking at 166-67.

Professor Fletcher dismisses as a mere "evidentiary rule," id. at 168 , the Code's requirement that the actor's conduct be "strongly corroborative of the actor's criminal purpose." That requirement applies some of the reasoning that underlies the "res ipsa loquitur" test favored by Salmond, see note 88 supra, but it is not so restrictive. It does not require that the criminal purpose be established exclusively by the act. See Model Penal Code $\$ 5.01$, Comment, at 49 (Tent. Draft No. 10, 1960).

92. The current approach is exemplified by United States v. Mandujano, 499 F.2d 370 (5th Cir. 1974).

93. Rethinking at 144.

94. Id. at 144-46.

95. Id. at 145 . 
Professor Fletcher suggests that one of the missing keys to a solution may be the principle of manifest criminality ${ }^{96}$ Of course, it is true that when an intended harm does not occur because the means employed are utterly incapable of success, if we include the means in the description of the act, then the person will not look like the kind of criminal he intends to be. So, to elaborate on one of Professor Fletcher's examples, if Mrs. Smith, believing that sugar is lethal, dumps some of it into Mr. Smith's coffee with the intention of poisoning him, so long as we describe her act as dumping sugar into his coffee, we shall not discern criminality and she will not be guilty of an attempt. But suppose she puts into his coffee the contents of the sugar bowl, which she believes contains arsenic (because she put it there for just such a purpose) but in fact contains sugar (the housekeeper having officiously cleaned the cupboard and refilled all the bowls). Or suppose she pours the contents of a box labeled "Arsenic" into the coffee, Mr. Smith (perhaps intending to poison her sometime!) having secretly removed the arsenic from the box and replaced it with sugar. It may be a question whether we ought to convict Mrs. Smith of attempted murder when she sweetens her husband's coffee. We do not find an answer to what puzzles us in any of those cases by looking at appearances. When we convict someone of attempted murder for administering an almost lethal dose of poison, it is not because she looks like a murderer but because she came dangerously close to being one. And when we acquit the evil-intentioned but utterly inept person-in fact a very rare case-it is not because he looks innocent but because he doesn't get the hang of it enough for us to take the danger seriously. ${ }^{97}$

96. See id. at 149-52. But see id. at 156-57 (indicating need for "an objectivist theory of liability that is not tied to criteria of manifest criminality").

97. Another example that Professor Fletcher gives, $i d$. at 149, illustrates the same point. Someone who shoots at a tree stump believing it to be a person whom he intends to kill may manifest criminality as full as someone who shoots at an empty bed believing that his intended victim is lying in it. It is not some "shared image" of a murderer that leads us to distinguish such cases but the degree and concreteness of the danger. Indeed, it is by no means clear that the law would invariably acquit the person who hits the stump and convict him who blows a hole in the mattress. A great deal would depend on the circumstances. Suppose the stump looked like a human being in the dark and were in just the place where the would-be killer had every reason to look for his victim, and the victim were in fact nearby. Suppose, on the other hand, the victim had left his bed and house empty months before the killer, just returned to the neighborhood from a long stay abroad, fired at the pillow.

Professor Fletcher fits the puzzles of "impossible attempts" to his theory by applying a test of manifest "aptness" of the means employed to the actor's purpose. "An apt attempt is one that manifests danger to the surrounding environment." Id. at 150. In so 


\section{Manifest Criminality}

How far back from actual harm we ought to reach with the crime of attempt is a question for which no unidimensional answer is likely to be adequate in every case. A secure, confident community will accept greater risks of harm than one that feels itself threatened by such harm. We may well disagree reasonably about what lines to draw and on which side of the lines particular cases fall. Except insofar as they indicate the intention to cause a prohibited harm or the immediacy of the danger, manifestations of criminality are not likely to aid us in answering those questions. Nor is it obvious in which direction the criterion of manifest criminality would lead. Were we to defer intervention until, having regard exclusively to the actor's present conduct, every possibility other than an intended crime was eliminated, we might have to wait, beyond reason, until the danger was realized. On the other hand, we might sometimes intervene sooner than we now do. One can readily imagine acts plausibly consistent only with an intended crime-studying the layout of a bank, procuring guns and masks, and so onthat are yet too far from its realization to constitute an attempt under some formulations of present law. ${ }^{98}$

Professor Fletcher's references to manifest criminality outside the area of larceny and attempts reinforce the conclusion that it has not been a pattern of the criminal law. He discusses manifest criminality in connection with the related theft offenses of embezzlement and false pretenses, only to acknowledge that it has not been, nor could it well be, of significance for those crimes. ${ }^{99}$ Burglary, he says, is more to his point; the common law's fine distinctions about which acts constituted a "breaking" and which did not are said to reflect "judgments designed to capture the manifest criminality in breaking and entering." 100 The examples he gives by way of illustration, however, are startingly unpersuasive. Opening a window or lifting the latch on a door was a "breaking"; but going

doing, he leaves our understanding of the puzzles where it was without the theory. Indeed, he acknowledges that his analysis in terms of manifest criminality is not generally applicable. Id. at 156-57, 159-60, 184.

98. See, for example, the facts described in United States v. Stallworth, 543 F.2d 1038 (2d Cir. 1976), in which the defendants' preparations for a bank robbery left no doubt of their purpose, before the commission of the crime was imminent.

99. RETHINKING at 122-24.

100. Id. at 126. Professor Fletcher describes Blackstone's observation that the felonious intent must be "demonstrated by some attempt or overt act," $4 \mathrm{~W}$. BLACKsToNE, supra note 40 , at $* 227$, as an "effort to retain the principle of manifest criminality." RETHINKING at 125-26. That is incorrect. The quoted phrase is part of a discussion about the element of intent. The "manner of committing burglary," that is to say the act, is the subject of another section. 4 W. BLACKSTONE, supra note 40 , at $* 226-27$. 
through an already open window was not. ${ }^{101}$ Can it seriously be entertained that someone who goes to a door, lifts the latch, and enters through the door manifests his criminality more than someone who climbs through an open window? Or that the act of opening the window before climbing in manifests criminality in a way that climbing through an already open window does not? Professor Fletcher explains the common law's distinction between going down a chimney, which was a breaking, and going through the open window with the observation: "In our ordinary experience, entering by the chimney is far more incriminating than entering by an open window." 102 From such examples, he derives a "general rule of manifest criminality" 103 in the crime of burglary-but he is obliged to acknowledge immediately that the common law ignored the "rule," since it recognized a fraudulent entry as a breaking, as well as a forcible entry. ${ }^{104}$ If such evidence indicates anything, it is that "manifest criminality" had nothing to do with the law's development and has scarcely any explanatory value. ${ }^{105}$

Professor Fletcher has said that the pattern of manifest criminality has no application to criminal homicide, ${ }^{106}$ as of course it could not. No "externally identifiable event" readily distinguishes all of the occasions of noncriminal homicide from murder or manslaugh-

101. RETHINKING at 126.

102. Id.

103. Id.

104. Id. at $126-27$.

105. Professor Fletcher discerns "the familiar theme of manifest criminality," RETHINKING at 200, in a scattering of other points of the criminal law. He suggests, for example, that it helps to explain why courts might accept an inference of guilty intent from the possession of items " "which experience teaches are generally held for illicit purposes' " more easily than from the possession of items that have common innocent as well as illegal purposes. Id. (quoting Benton v. United States, 232 F.2d 341, 345 (D.C. Cir. 1956)). One requires no theory of manifest criminality to understand such reasoning. He finds traces of manifest criminality in the crime of treason, citing language of Coke that is at best ambiguous on the point, E. Coke, supra note 43 , at 5, and a few extracts from cases in the Supreme Court; but he concludes that in fact manifest criminality plays no part in that crime. RETHINKING at 207-18. Relying on a remark in the legislative commentary to a draft of the proposed federal criminal code, he speculates that "the law of conspiracy" may "witness a resurgence of the principle of manifest criminality." Id. at 224-25. The context in which the remark appears is unmistakably contrary to the implication he draws from it. SENATE Comm. on the Judiciary, 94th Conc., Ist Sess., Criminal Justice Reform Act of 1975 at 181 (Comm. Print 1975). It is, of course, well-settled law that the requirement of an overt act, with which the remark that he quotes is concerned, has nothing whatever to do with "manifest criminality." Finally, Professor Fletcher believes that in the initial stop-andfrisk cases, Terry v. Ohio, 392 U.S. 1 (1968); Sibron v. New York, 392 U.S. 40 (1968), the Justices were "drawn intuitively" to the principle of manifest criminality. Id. at 228. To such argument, one can only respond, "Well, if you say so." It is, in any event, certain, as he recognizes, that the force of the principle was altogether spent four years later, when the Court decided Adams v. Williams, 407 U.S. 143 (1972). See Rerhinking at 230.

106. Rethinking at $121,233,235$. He also excludes from the scope of his theory a number of other crimes. See id. at 233-34. 
ter or distinguishes among the various categories of criminal homicide, like voluntary manslaughter and second and first degree murder, that turn on the actor's intent. The failure of his theory with respect to homicide, however, is only a particularly obvious example of its general weakness. ${ }^{107}$ Its superficial plausibility depends on one's attending narrowly to the sort of aggression against the person or property of another, like paradigmatic larceny, that "could not" have an innocent purpose or be prompted innocently by a mistake. Even when the theory "works," it does not take us beyond what we know without it: that often it is possible, in the absence of unusual circumstances, to infer a person's intention directly from his act.

The complexities and ambiguity of human behavior and interaction are too great for us to rely on appearances as heavily as the theory of manifest criminality requires. Our assessment of conduct depends too much on the reasons why a person acts as he does, the purposes that motivate him, which do not invariably display themselves. Recognition of that moral dimension of our experience lies behind the consistent emphasis in the criminal law on criminal intent as a separate, independently significant element of liability. To subordinate the emphasis on intent in favor of manifest criminality would to that extent deprive criminal law of the element that makes it most distinctively applicable to human behavior. It would blunt the law's capacity to take account of distinctions that we feel deeply to be important.

Nor is it easy to see that it would benefit our liberty. Professor Fletcher professes to see dangers of oppression in the emphasis on intention, against which the principle of manifest criminality provides protection. In particular, he evidently fears that the criminal law will punish for "bare" intentions or dangerous propensities unaccompanied by behavior that the law properly prohibits. ${ }^{108} \mathrm{He}$ gives no concrete evidence that such danger lurks in our insistence that criminal behavior be accompanied by criminal intent, however. ${ }^{109}$ It may be, as he urges, that the definition of some crimes

107. The reason why the inapplicability of the theory to homicide is so obvious is that the forms of criminal homicide refer explicitly to distinctions according to the actor's intent that are not "externally" visible in the act of killing itself. The same difficulty is present, albeit less obviously, in other crimes that make criminal intent crucial but do not make so many distinctions on that basis.

108. St' $S^{\prime}$ pp. $294-95$ \& note 9 supra.

109. Professor Fletcher makes a good deal of the decision in People v. Ashley, 42 Cal. 2d 246, 267 P.2d 271 (1954), in which the California Supreme Court "boldly" held that a misrespresentation of intention could sustain the charge of obtaining property by false pretenses. Rethinking at 11-12; Fletcher, supra note 7, at 523-24, 526-27. The decision, although contrary to the prevailing rule that requires a misstatement of an "existing fact" 
has moved the prohibited act too far back from the harm to be avoided. ${ }^{110}$ Surely the way to guard against that is not to minimize the importance of criminal intent but to insist as strongly that the area of prohibited behavior not be needlessly expanded. It is worth noting that insistence on criminal intent as an element of crime has been, if anything, characteristic of those most concerned to guard against oppressive results. ${ }^{111}$

Professor Fletcher argues that although manifest criminality would not be sufficient to convict, the defendant always having the possibility of proving that in his case the criminality manifest in his behavior was deceptive, its absence would be enough to acquit and presumably to cut off further investigation. How seriously can we take the argument that those who frame the law and those who apply it would or should disregard conduct, however threatening or harmful, that was not criminal on its face? Were that the threshold that had to be crossed, it is far more likely that a great deal of conduct that is not unambiguously criminal would be deemed to cross it, because otherwise, conduct (accompanied by criminal intent) that we believe should be criminal would escape. ${ }^{112}$ The great danger of a conceptual framework based on manifest criminality is that we should become captivated by our own labels and accept too readily a presumption of actual criminality from that starting point, leaving it to the defendant to establish the contrary if he can. To shift our attention away from the harm and toward behavior manifesting criminality would make it not harder but easier for the criminal law to sweep up conduct that is better left private. Harm and intent to commit harm, however difficult the latter sometimes may be to establish, tie conviction for crime to what is actually the case. Manifest criminality, for all its vaunted reliance on the "external" world of events, depends too much on appearances. "Criminality," like beauty, too often is in the eye of the beholder.

other than the actor's present intention, e.g., Chaplin v. United States, 157 F.2d 697 (D.C. Cir. 1946), was not novel. The federal mail fraud statute had been interpreted more than fifty years earlier to include fraudulent representations of intention. Durland v. United States, 161 U.S. 306 (1896). The opinion in Ashley refers to other earlier decisions or legislation to the same effect. $42 \mathrm{Cal} .2 \mathrm{~d}$ at 261,267 P.2d at 280-81. The Reporters for the Model Penal Code inquired among the jurisdictions allowing prosecutions for false promises whether the kind of abuse that Professor Fletcher imagines had occurred; the answers were "uniformly negative." Model Penal Code $\$ 223.3$, Comment, at 69 (Tent. Draft No. 2, 1954). The Model Penal Code adopts the rule of Ashley. Id. § 223.3.

110. If one puts aside the obvious federal jurisdictional concern, Professor Fletcher's example of interstate travel for a prohibited purpose fairly puts that question. See RETHINKING at 130-31.

111. E.g., Hart, supra note 11.

112. See pp. 310-15 supra. 